\title{
Contribution of walleye pollock eggs to the Gulf of Alaska food web in spring
}

\author{
Jens M. Nielsen*, Lauren A. Rogers, David G. Kimmel, Alison L. Deary, \\ Janet T. Duffy-Anderson
}

National Oceanic and Atmospheric Administration, Alaska Fisheries Science Center, 7600 Sand Point Way NE, Seattle, WA 98115, USA

\begin{abstract}
Pulsed resources are prevalent phenomena in nature that can have disproportionally large and long-lasting effects on ecosystem production. Many fishes aggregate and spawn at high densities and release large amounts of resources to the environment in the form of eggs. These spawning events can provide pulsed dietary resources for a range of consumers; however, this is still an understudied topic particularly in the Gulf of Alaska food web. Here we assessed the magnitude and timing of eggs from walleye pollock Gadus chalcogrammus and their energy contribution to a highly productive ecosystem in Shelikof Strait, Gulf of Alaska. Our results show that aggregate spawning events of walleye pollock contribute considerably to the resource fluxes of this coastal food web in spring. Walleye pollock egg resources constituted on average $18.9 \%$ of April and $5.8 \%$ of May copepod production in the Shelikof Strait marine food web. In addition, the resource contributions from eggs appear 1 to $3 \mathrm{wk}$ earlier than the spring peak rates of zooplankton production and thus occur at a time when equivalent dietary resources are still limited for many consumers. Our analysis showed that spawning events of walleye pollock provide an important pulsed resource subsidy in the Gulf of Alaska ecosystem.
\end{abstract}

KEY WORDS: Egg boon - Trophic transfer - Gulf of Alaska - Ecosystem production · Fishes · Zooplankton · Walleye pollock · Gadus chalcogrammus

${ }^{*}$ Corresponding author: jens.nielsen@noaa.gov

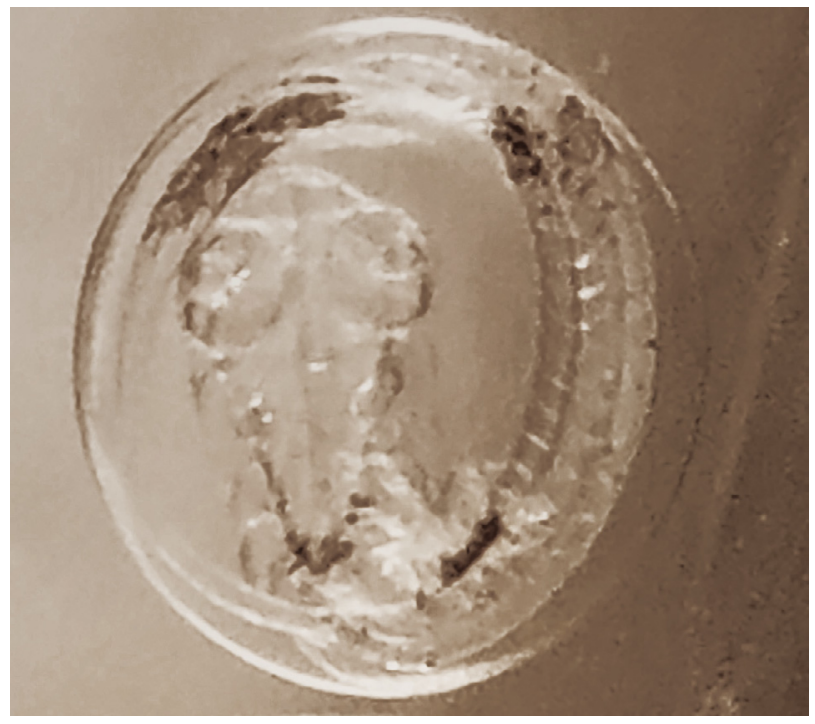

Walleye pollock, Gadus chalcogrammus, egg boons provide energy to the Gulf of Alaska food web.

Photo: Alison L. Deary, NOAA Fisheries

\section{INTRODUCTION}

Pulsed resources, i.e. intense but brief periods of high resource availability (Yang et al. 2008), are prevalent phenomena in nature (Jentsch \& White 2019). Despite being punctuated events, resource pulses often have disproportionally large and longlasting effects on ecosystem production (Holt 2008, Yang et al. 2008, Lewandowska et al. 2015). In midto high-latitude ecosystems, seasonality is a major

Outside the USA @ The U.S. Government. Open Access under Creative Commons by Attribution Licence. Use, distribution and reproduction are unrestricted. Authors and original publication must be credited.

Publisher: Inter-Research · www.int-res.com 
forcing factor, and consequently, pulsed resource subsidies often vary tremendously in time and space (Yang \& Naeem 2008) and quality and quantity (Richardson \& Wipfli 2016). Yet, the timing and magnitude of resource pulses are sensitive to environmental fluctuations and are organism specific, something that in turn influences consumer growth, survival and reproduction (Chmura et al. 2019). In fact, differential shifts in consumer-resource phenologies are common (Kharouba et al. 2018) and can lead to greater consumer-resource synchrony or alternatively trophic mismatches (Cushing 1990, Neuheimer et al. 2018), which can have widespread impacts on food web dynamics and production (Holt 2008). The importance of a resource pulse ultimately depends on its magnitude and timing relative to the consumer, and to what extent it occurs when equivalent resources are limiting (Richardson \& Wipfli 2016).

Many fish species aggregate and spawn at high densities, releasing large amounts of energy and nutrients to the environment (Barneche et al. 2018). In addition to primary- and secondary-derived production, pulsed resources released during spawning events, also referred to as egg boons (Fuiman et al. 2015), can provide important resource subsidies in marine food webs (Polis et al. 1997). For example, Atlantic cod Gadus morhua (Kjesbu et al. 1991), Pacific herring Clupea pallasii (Fox et al. 2014), Atlantic herring C. harengus (Varpe et al. 2005) and tropical reef fishes (Nemeth 2009) all aggregate in high numbers during spawning and contribute resources to marine food webs in the form of eggs. Similarly, salmon eggs and other nutritional components, such as milt and adult carcasses, provide important subsidies for both fishes and mammals in freshwater ecosystems (Armstrong et al. 2016 and references therein). For both salmon and Pacific herring, spawn timing varies across spatial gradients, and thus several successive resource pulses, i.e. resource waves (Armstrong et al. 2016), provide extended subsidies for consumers that migrate across the landscape or seascape (Lok et al. 2012).

Fish eggs have high energy content but are vulnerable to predation by a range of small to large predators due to their small sizes (Bunn et al. 2000). A range of consumers, including pelagic fishes, invertebrates, detritivores and decomposers (Brodeur \& Merati 1993, Bunn et al. 2000, Kuribayashi et al. 2017) all forage on fish eggs, while higher trophic level consumers also prey on the adults during spawning aggregations (Nemeth 2009, van Deurs et al. 2016). Fish eggs, through maternal inputs, are rich in essential long-chained polyunsaturated fatty acids (Laurel et al. 2010, Fuiman 2018), which can be a limiting resource in both freshwater (Brett \& Muller Navarra 1997) and marine systems (Litzow et al. 2006). Despite their significance in terms of providing resource pulses for fueling ecosystem production (Erisman et al. 2017, Šmejkal et al. 2017), the importance of egg boons is still an understudied topic.

The Gulf of Alaska is a highly productive boreal ecosystem. Peaks in primary and secondary production commonly occur in early to mid-May (Waite \& Mueter 2013) and provide resources to support large numbers of higher trophic level species (Adams et al. 2007). Due to their high abundance, walleye pollock Gadus chalcogrammus are a key trophic linkage in the Gulf of Alaska food web as both predators and prey (Springer 1992). Walleye pollock are a primary prey species for seabirds, marine mammals and other adult fishes (Adams et al. 2007), whereas this species in turn preys on many invertebrates, particularly euphausiids (Urban 2012), and adult and younger life stages of other fishes (Adams et al. 2007). Walleye pollock also support a large commercial fishery, and have experienced large annual to decadal scale oscillations in abundance (Dorn et al. 2017), with consequent impacts on spawning stock biomass and recruitment (Ciannelli et al. 2005). In the Gulf of Alaska, walleye pollock aggregate in a relatively restricted area and spawn at depth (150-250 m) at high densities in early spring (e.g. estimated female spawning stock biomass in 2017 was $3.5 \times 10^{5} \mathrm{t}$; Dorn et al. 2017), primarily in Shelikof Strait (Kendall et al. 1996). Walleye pollock eggs are primarily found at depths between 150 and $250 \mathrm{~m}$ but rise during development, while later in spring eggs also appear closer to the surface (Kendall 1994). As is common for marine fishes (Llopiz et al. 2014), mortality of walleye pollock eggs and larvae is high (Brodeur et al. 1996). Previous studies on walleye pollock egg and larval ecology have focused on survival in relation to recruitment dynamics; however, no study has assessed the fate of the majority of walleye pollock eggs that do not survive (commonly >95\%, Brodeur et al. 1996). A range of other species, such as gammarid amphipods, euphausiids and fishes, forage on walleye pollock eggs and larvae (Bailey et al. 1993, Brodeur \& Merati 1993). Therefore, walleye pollock eggs may provide an important resource subsidy to the Gulf of Alaska food web.

Here, we combine modeling with extensive empirical data on walleye pollock from Shelikof Strait, and for the first time assess the magnitude and timing of eggs as a resource in this productive coastal ecosys- 
tem. We contrast the walleye pollock egg boons to zooplankton production based on the assumption that consumers that prey on zooplankton also forage on walleye pollock eggs and larvae which are of similar size (Brodeur et al. 1991, Fuiman et al. 2015; see Fig. S1, Table S1 in the Supplement at www.intres.com/articles/suppl/m632p001_supp.pdf). Larval survival is critically dependent on the timing of available zooplankton resources during first feeding (Hjort 1914). Walleye pollock spawn in early to midApril (Matarese et al. 2003) and have egg and endogenous larval phases of approximately $14 \pm 2 \mathrm{~d}$ (Hinckley 1990) and $7 \pm 2$ d (Porter \& Theilacker 1999), respectively, thus first feeding larvae require adequate resources around $3 \mathrm{wk}$ after spawning. If spawning occurs so that larvae hatch when food availability is high (Platt et al. 2003, Burrow et al. 2011), the eggs will be spawned around $3 \mathrm{wk}$ in advance, and potentially before the initiation of the main pulse of phytoplankton and zooplankton production. Accordingly, we hypothesized that: (1) Walleye pollock egg boons contribute significant resources to the Shelikof Strait ecosystem on the same order of magnitude as spring zooplankton production. (2) The timing of walleye pollock egg boons precedes the rapid increase in zooplankton production in spring, providing a resource subsidy for consumers during a time period when equivalent resources such as zooplankton prey are still limited.

\section{MATERIALS AND METHODS}

\subsection{Approach}

We used data from long-term monitoring efforts by the Alaska Fisheries Science Center Ecosystems and Fisheries-Oceanography Coordinated Investigations program (EcoFOCI Kendall et al. 1996) and previously published empirical values to evaluate the magnitude and timing of walleye pollock egg boons in Shelikof Strait, Gulf of Alaska (Fig. 1). To evaluate our Hypothesis 1, first we calculated the total and average daily energetic contribution of eggs to the marine food web in spring. Second, we estimated primary and zooplankton production rates during the same period. Third, we modeled annual changes in egg boon phenology by coupling our egg production calculations with previous estimates of walleye pollock spawn timing (Rogers \& Dougherty 2019). To assess the timing hypothesis, we contrasted egg boon phenology to zooplankton development times of Neocalanus copepodite Stage V (CV) stages, which are the species that

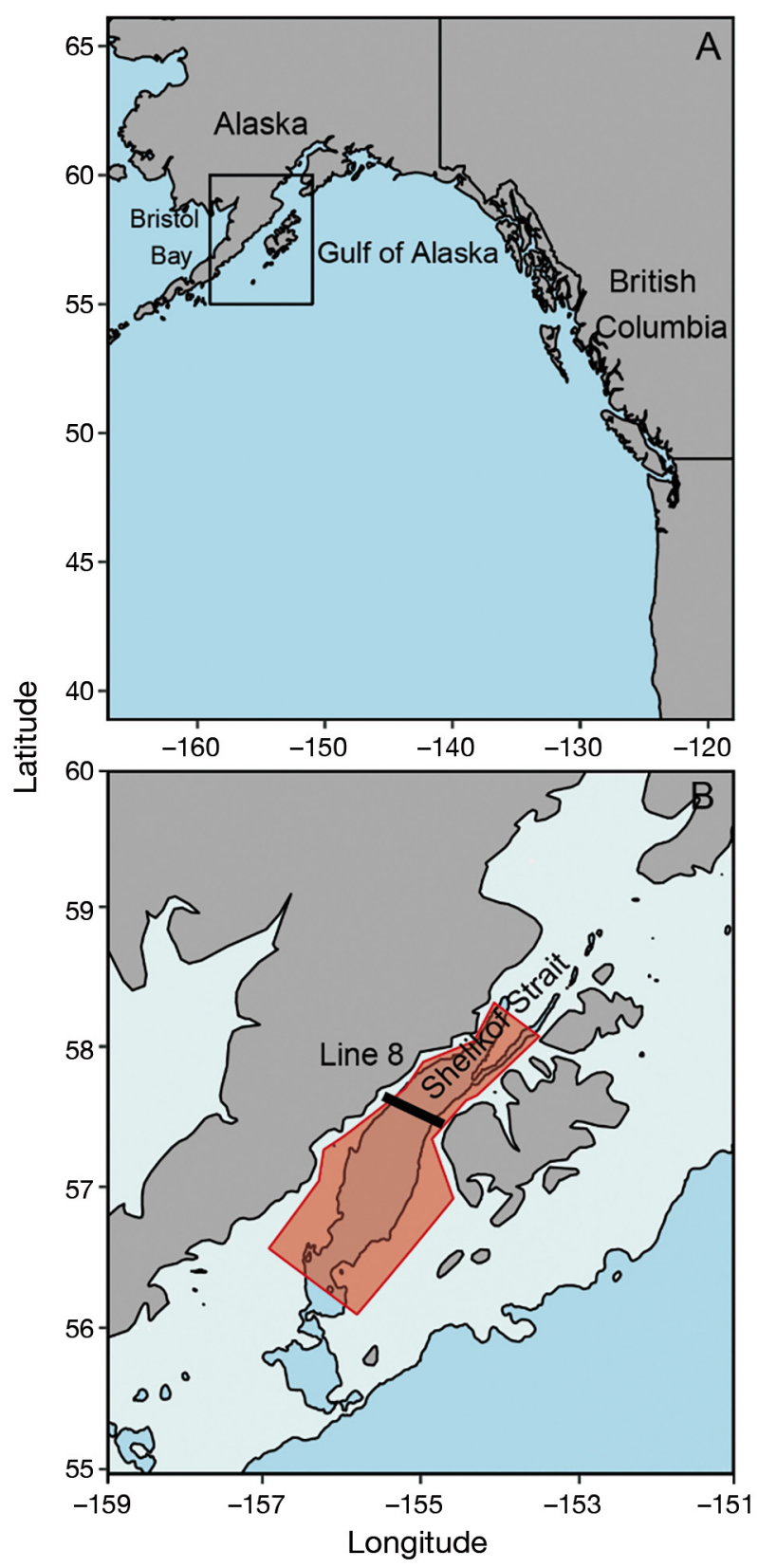

Fig. 1. Overview of (A) the Gulf of Alaska area and (B) Shelikof Strait, showing the area used for the egg boon estimates (red shaded area) and Line 8 (solid line), the collection area of the zooplankton data. Bathymetry line in (B) denotes the $200 \mathrm{~m}$ depth contour

have the highest biomass and represent the majority of zooplankton production in spring. All egg and plankton estimates were calculated as rates of production in $\mathrm{mgC} \mathrm{m} \mathrm{m}^{-2} \mathrm{~d}^{-1}$. Production estimates were considered informative, as they provide the rate of energy (often expressed in carbon units) generated over time, while biomass estimates give a static measure of the current standing stock (Jenkins 2015). 


\subsection{Calculation of egg resources in Shelikof Strait}

Total egg production from spawning was calculated based on (1) the total number of eggs spawned, (2) the proportion of eggs that do not survive the egg stage, which is a function of egg mortality and incubation time, and (3) the energy content of an egg. Only non-surviving eggs were considered, as those are the resources made available to the ecosystem.

The annual number of walleye pollock eggs spawned was calculated by combining female spawning stock biomass estimates (Dorn et al. 2017) and female fecundity from the Shelikof Strait. Annual female spawning stock biomass was estimated based on acoustic surveys in Shelikof Strait (1981-2017) taking into account the age structure of the population, the proportion mature-at-age, and assuming a 50\% female-to-male ratio (Stienessen et al. 2017). An average value of female fecundity of 472.1 eggs $^{-1}$ body weight (range: 427.5538.0) was used based on previous studies by Picquelle \& Megrey (1993), Kim \& Gunderson (1989) and Miller et al. (1986) (Table S2, Fig. S2).

Based on the total number of eggs spawned ( $\left.N_{\text {eggs }}\right)$, the total number of non-surviving eggs was calculated as:

$$
\text { Non-surviving eggs }=N_{\text {eggs }} \times\left(1-\mathrm{e}^{-M \times I T}\right)
$$

where $M$ is the daily mortality rate and $I T$ is the incubation time. Daily egg mortality estimates vary from 0.06 to $0.30 \mathrm{~d}^{-1}$ (Picquelle \& Megrey 1993, Brodeur et al. 1996); we used a value of 0.2 (Table S2). Incubation time was on average $14 \mathrm{~d}$, although it can range from 12 to $16 \mathrm{~d}$ depending on temperature (Blood 1994).

Based on the number of non-surviving eggs, average daily egg production $\left(\mathrm{mgC} \mathrm{m}^{-2} \mathrm{~d}^{-1}\right)$ during the spawning season in the Shelikof Strait was calculated as:

$$
\text { Egg production }=\sum \frac{\text { Non surviving eggs } \times W_{\text {egg }} \times C_{\text {conv }}}{A \times S D}
$$

where $W_{\text {egg }}$ is the egg dry weight (DW, in mg). For the egg weight, we used a mean value of $0.12 \mathrm{mg}$ DW based on Hinckley (1990), who also provided the total range of egg weights as 0.097-0.139 $\mathrm{mg}$ DW based on estimates from 1319 walleye pollock eggs (Table S2). Similar values with a mean of 0.117 (0.101-0.125 mg DW) were estimated by Laurel et al. (2018). $C_{\text {conv }}$ is the DW to carbon ratio of $35.3 \%$ (range 29.2-39.6\%; Harris et al. 1986). $A$ is the area of the Shelikof Strait, which was estimated as 17586 $\mathrm{km}^{2}$, using ArcGIS v.10.4.1 (Fig. 1). $S D$ is the spawn duration, here assumed to be $34 \mathrm{~d}$ based on the median duration of the spawning season previously estimated for the walleye pollock population (Rogers \& Dougherty 2019). A median spawn time duration of $34 \mathrm{~d}$ was used to allow for comparison between the total spring egg production estimates and the April and May zooplankton production rates where we did not have specific data on biomass peaks and phenology. Egg production estimates were calculated for each year for the time period 1981-2017 (excluding the years 1982, 1987, 1999 and 2011 when data were not available). Additional information about the input data and associated references are available in the Supplement. For the primary egg production model described above, we used average literature values for each input parameter, while the ranges of each parameter were used to assess uncertainties of our estimates (Table S2). Based on the parameter ranges in Table S2, we assessed the sensitivity of our egg production calculations. In this simulation, we used the mean egg number $1.06 \times 10^{14}$ based on the mean female spawning stock biomass from the annual surveys, and the average fecundity, and systematically varied each parameter across the range of empirically measured values. A similar sensitivity analysis was performed for zooplankton production as it relates to temperature (Figs. S5 \& S6). All analyses were conducted using R (R Core Team 2018).

\subsection{Phytoplankton and zooplankton production estimates}

To compare the relative importance of the egg boons in terms of magnitude and timing, net primary production and April and May zooplankton production were estimated. Net primary production for the Shelikof Strait (areas $55-60^{\circ} \mathrm{N}$ and 150$160^{\circ} \mathrm{W}$ ) was estimated from MODIS data (www. science.oregonstate.edu/ocean.productivity/standard. product.php) and calculated following a vertically generalized production model, based on $8 \mathrm{~d}$ averaged MODIS surface chlorophyll concentrations, sea surface temperature and cloud-corrected photosynthetically active radiation, and presented as mgC $\mathrm{m}^{-2} \mathrm{~d}^{-1}$ (Behrenfeld \& Falkowski 1997).

We calculated daily production rates for each copepod taxon and stage as $P=N W g$, where $P$ is production $\left(\mu \mathrm{gC} \mathrm{m} \mathrm{m}^{-3} \mathrm{~d}^{-1}\right), N$ is the number of individuals $\left(\mathrm{m}^{-3}\right), W$ is the individual biomass $(\mu \mathrm{g})$, and $g$ is the growth rate $\left(\mathrm{d}^{-1}\right)$. The number of individuals $(N)$ was measured using counts from net tows (see Kimmel et al. 2018 for net tow details) conducted annually between 1990 and 2011 and biennially thereafter. 
Biomass $(W)$ was estimated using literature values of dry weight for each taxon and stage (Table S3). Biomass was converted to carbon assuming $40 \%$ of DW is comprised of carbon (Bamstedt 1986). Growth rate $(g)$ was estimated using equations from the literature (Table S4). Temperature values for the growth rates were calculated using water temperature at $50 \mathrm{~m}$ depth obtained from the University of Alaska Fairbanks oceanographic station GAK1, located at $59^{\circ}$ $50.7^{\prime} \mathrm{N}, \quad 149^{\circ} 28.0^{\prime} \mathrm{W}$ (http://research.cfos.uaf.edu/ gak1/). Average temperature data for April or May were used for the production estimates of that specific month. For the years 1990, 1997 and 2009, the May temperatures were not measured. Instead, for 1997 and 2009 we used EcoFOCI SeaCAT data at $50 \mathrm{~m}$ to calculate the production estimates, while for 1990 we used the long-term May average from the GAK1 line. Production estimates were summed across all species and life-history stages and integrated over a depth of $120 \mathrm{~m}$ to yield estimates in terms of $\mathrm{mgC} \mathrm{m}^{-2} \mathrm{~d}^{-1}$. A depth of $120 \mathrm{~m}$ was used since the mixed layer depth averages $\sim 120 \mathrm{~m}$ at GAK1 in spring (Sarkar et al. 2005), and because previous studies have shown that the majority of the zooplankton production occurs above this depth (Napp et al. 1996, Coyle \& Pinchuk 2005).

\subsection{Phenology of egg production and plankton}

Annual estimates of daily egg production phenology were modeled based on previous walleye pollock spawn timing estimates (Rogers \& Dougherty 2019). Spawning of the walleye pollock population in Shelikof Strait commonly follows a normal distribution with a median peak timing in early April, but it can shift annually up to $24 \mathrm{~d}$, and the spawn duration also varies among years, from 16 to $57 \mathrm{~d}$ (Rogers \& Dougherty 2019). Daily egg releases for each year were modeled, as the total spawned eggs normally distributed over time (Eq. 1) from start to end of spawning. We then modeled the daily energy contributions of non-surviving eggs in terms of carbon production (Eq. 2) for each year for the time period 1981-2017 (excluding the years 1982, 1984, 1987, 1999 and 2011, 2014, 2016 and 2017, when data were not available for either spawn timing or female spawning stock biomass).

We compared the egg phenology estimates to development times of the CV stage of the copepods Neocalanus cristatus and Neocalanus flemingeri/ plumchrus (hereafter Neocalanus spp.) because they are the dominant contributors to zooplankton biomass during the spring peak in the Gulf of Alaska (Coyle \& Pinchuk 2003, Sousa et al. 2016). The life cycle of both $N$. cristatus and the congeners labelled as Neocalanus spp. are similar in the Gulf of Alaska region. $N$. cristatus reproduces at depth, primarily in November, emerges in spring, develops to the CV stage by May/June and enters diapause in June/July (Miller et al. 1984, Kobari \& Ikeda 1999). Neocalanus spp. reproduce in January and February at depth, emerge in spring, develop to CV stage and enter diapause in June (Liu \& Hopcroft 2006). We designated the egg release date for $N$. cristatus as 15 November and for Neocalanus spp. as 1 January to match the months of peak reproduction (Miller et al. 1984). Developmental times for the CV stages were estimated using the equation:

$$
\kappa=\ln \left(\frac{C W}{E W}\right) / g
$$

where $\kappa$ is the developmental time in days, $C W$ is the carbon mass of stage $C V$, and $E W$ is the copepod egg mass, both in $\mu \mathrm{g} \mathrm{C}$, and $g$ is the growth rate, assumed to be constant over time (Kiørboe \& Hirst 2008). We estimated copepod egg mass and CV stage mass from the literature (Table S3). We used the mean temperature from Station GAK1 for the period January-May as an estimate for the temperature regime experienced by developing copepods.

\section{RESULTS}

On average, walleye pollock egg production was $7.1 \mathrm{mgC} \mathrm{m}^{-2} \mathrm{~d}^{-1}$ (Fig. 2A). Production varied by over an order of magnitude depending on the year, with the lowest production in $2008\left(0.8 \mathrm{mgC} \mathrm{m}^{-2} \mathrm{~d}^{-1}\right)$, and the highest production in $1981\left(32.6 \mathrm{mgC} \mathrm{m}^{-2} \mathrm{~d}^{-1}\right.$; Fig. 2B). The uncertainty of these single annual estimates modeled from annual egg numbers and the mean empirical input parameters was assessed with a sensitivity analysis (Table S2, Fig. S4). This analysis showed that the influence of each parameter altered estimates of egg production by no more than $25 \%$, with mortality, female fecundity and egg weight the most influential parameters (Fig. S4). Our total egg estimates also generally matched well with previous results based on repeated empirical measurements of eggs at different development stages that were done for some years in the Shelikof area (Fig. S3, Kim \& Gunderson 1989, Picquelle \& Megrey 1993, Brodeur et al. 1996). The sensitivity analysis and comparison with previous data indicated that our egg calculations should be indicative of the magnitude of the 

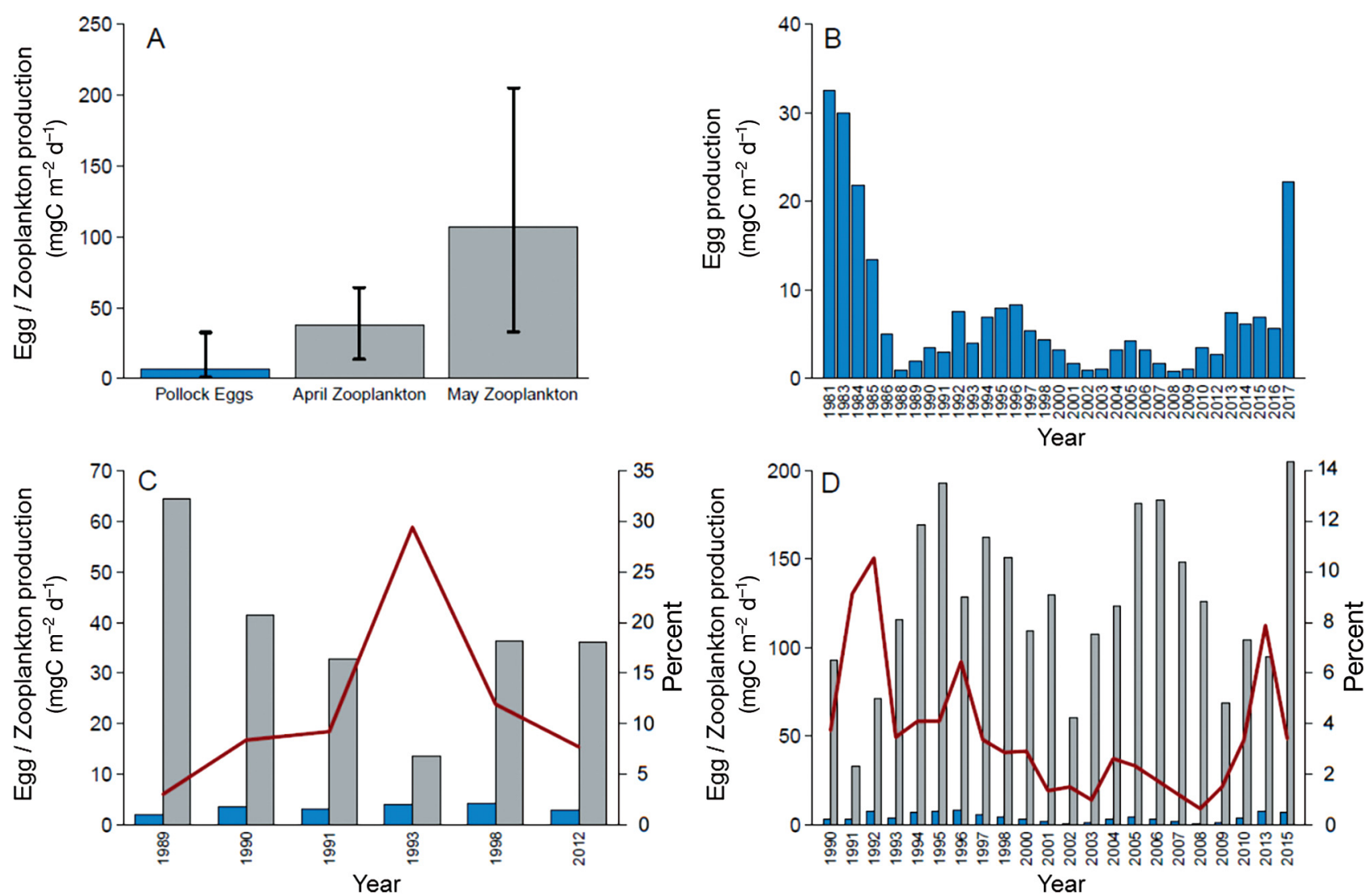

Fig. 2. Overview of egg and zooplankton production estimates. (A) Average production $\left(\mathrm{mgC} \mathrm{m}^{-2} \mathrm{~d}^{-1}\right)$ of walleye pollock eggs, and April and May zooplankton for all years. (B) Annual walleye pollock egg production. (C,D) Comparisons of annual walleye pollock egg production (blue) with (C) April zooplankton (grey) and (D) May zooplankton (grey) production. Red lines in C and D denote the relative proportion of walleye pollock egg production compared to total zooplankton production

annual egg boon in the Gulf of Alaska, even if such estimates carry uncertainties.

Next, we compared the relative importance of fish egg production estimates to spring copepod production, as this was considered an equivalent resource for potential predators due to the similarity in sizes between eggs and zooplankton (Fig. S1). April zooplankton production averaged $37.5 \mathrm{mgC} \mathrm{m}^{-2} \mathrm{~d}^{-1}$ (range: 13.7-64.4), while average May zooplankton production was $121.0 \mathrm{mgC} \mathrm{m}^{-2} \mathrm{~d}^{-1}$ (range: $33.1-205.3$, Fig. 2A). The influence of variable temperature on copepod production rates was overall low; instead, variation in copepod biomass was the main driver of annual production estimates (Figs. S5 \& S6). Only Oithona sp. and Pseudocalanus sp. production estimates varied substantially with changing temperatures, although the biomass contribution of these copepods to overall production was minimal.

On average, walleye pollock egg production was $18.9 \%$ compared to April and 5.8\% compared to May average zooplankton production. A total of 6 years allowed for year-specific comparisons between April zooplankton and egg production (1989-1991, 1993, 1998 and 2012; Fig. 2C), while comparisons with May zooplankton production were possible for 24 years during the time period 1990-2015 (Fig. 2D). The annual walleye pollock egg production ranged between 3.0 and $29.4 \%$ of April zooplankton production depending on the year (Fig. 2C). Egg production was between 0.6 and $10.6 \%$ of May zooplankton production (Fig. 2D). However, no direct annual comparisons were possible when fish egg production was at peak values (>20 $\mathrm{mgC} \mathrm{m}^{-2} \mathrm{~d}^{-1}$; e.g. 1981, 1983, 1984 and 2017).

The phenology of an early (1996), average (2013) and late spawn year (2009) was modeled based on previous spawn timing estimates from Rogers \& Dougherty (2019). Overall differences in peak egg production were $25 \mathrm{~d}$ among years (Fig. 3A,C). For the earliest spawning year (1996), egg production peaked on day of year (DOY) 100 at $21.3 \mathrm{mgC} \mathrm{m}^{-2} \mathrm{~d}^{-1}$ (Fig. 3A), while for the average year (2013) produc- 

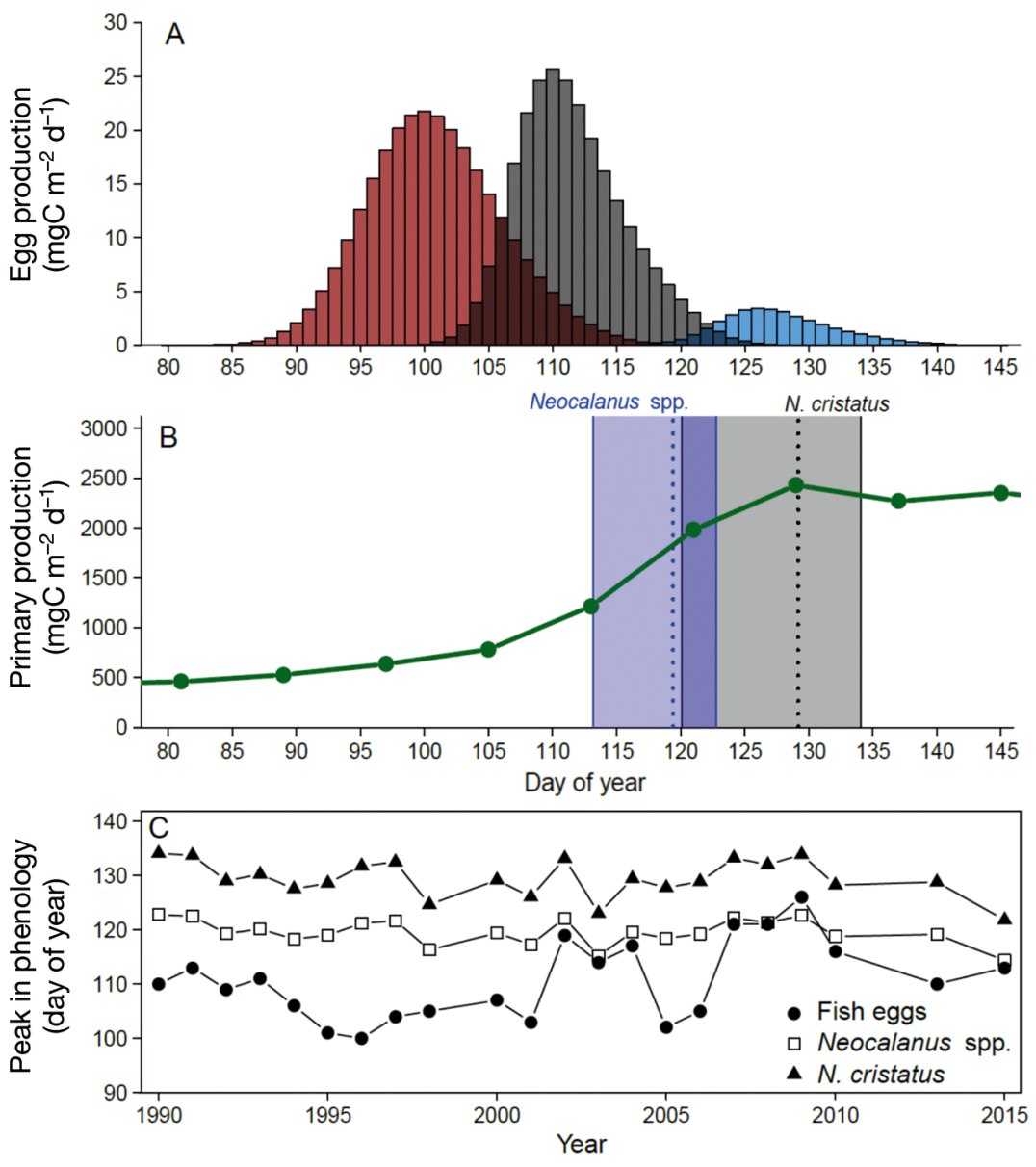

Fig. 3. Daily egg production for (A) an early (1996, red), average (2013, grey) and late (2009, blue) year of walleye pollock spawning. (B) Phenology of primary production (green) and the range (shaded areas) and mean (dotted lines) of Neocalanus cristatus copepodite stage V (CV) (black) and Neocalanus spp. CV (blue), and (C) annual peak timing for fish eggs (circles), Neocalanus spp. CV (open squares) and $N$. cristatus CV (triangles) production. Phenology of egg production for each year was modeled based on spawn timing estimates from Rogers \& Dougherty (2019). Average net phytoplankton production in spring was modeled based on MODIS data (Behrenfeld \& Falkowski 1997), while Neocalanus CV development times were estimated based on measurements and equations provided in Tables S3 \& S4

tion of non-surviving eggs peaked on DOY 110, with a peak of $25.5 \mathrm{mgC} \mathrm{m}^{-2} \mathrm{~d}^{-1}$. Peak egg production for the late year (2009) occurred on DOY 126, with a low peak production of $3.5 \mathrm{mgC} \mathrm{m}^{-2} \mathrm{~d}^{-1}$.

Data for zooplankton development time to the $\mathrm{CV}$ stage for the 2 taxa ( $N$. cristatus and Neocalanus spp.) were used as a proxy for estimating the timing of spring zooplankton production. Annual development time for $N$. cristatus to reach stage CV occurred, on average, on DOY 129 (range: 120-134; Fig. 3B), while for Neocalanus spp., average time to reach stage CV occurred on DOY 120 (range: 113-123). Long-term empirical zooplankton biomass data from the Shelikof
Strait supported the development time calculations and showed that the general peak of stage CV N. cristatus and Neocalanus spp. occurred, on average, between DOY 125 and 150 for both species (Fig. S7). Phytoplankton production onset was fairly consistent for almost all years and occurred, on average, around DOY 110 (Fig. 3B); however, since the MODIS chl a data are based on 8 d averages, there is an inherent uncertainty of $\pm 4 \mathrm{~d}$ for those estimates. While the timing of phytoplankton production onset was consistent, the magnitude varied substantially among years (Fig. S8).

On average, peak walleye pollock egg production occurred about 19 d earlier than peak $\mathrm{CV}$ abundance of $N$. cristatus and $9 \mathrm{~d}$ earlier than peak CV abundance of Neocalanus spp. (Fig. 3C). The biggest difference occurred in 1996, when walleye pollock peak egg production was 32 and $21 \mathrm{~d}$ earlier than $N$. cristatus and Neocalanus spp., respectively. Only in 1 year (2009) did peak egg production occur after the peak CV abundance of Neocalanus spp. The consistently earlier occurrence of the egg boons indicates that this resource is commonly available to other consumers before the increase in zooplankton production in spring.

\section{DISCUSSION}

\subsection{Egg energy contribution in spring}

Aggregate spawning events of walleye pollock contributed considerably to the energy and nutritional fluxes of the Shelikof Strait marine food web through the introduction of eggs into the ecosystem, supporting our first hypothesis. The annual contribution of walleye pollock egg production was, on average, $18.9 \%$ of April, and $5.8 \%$ of May zooplankton production. Spawning is a contracted occurrence both in space and time, and thus while walleye pollock egg boons may contribute little to total annual ecosystem production, it appears to provide an important resource subsidy for predators during the weeks of peak spawning. In the Gulf of Alaska, walleye pollock eggs are consumed by a range of predators, including adult walleye pollock, 
other fishes, decapods, amphipods, euphausiids and jellyfish (Bailey et al. 1993, Brodeur \& Merati 1993, Brodeur et al. 1996). Previous estimates of egg consumption show that particularly euphausiids and gammarid amphipods can consume up to $20-30 \%$ of eggs in the water column while cannibalism can also be substantial (Bailey et al. 1993, Brodeur \& Merati 1993). How much the eggs contribute quantitatively to the energy budgets of these consumers is unknown. In other systems, pelagic fish egg consumption by planktivorous fishes and gelatinous predators can be as much as 30-70\% of the natural egg mortality (Hunter 1980, Ellis \& Nash 1997) and contribute up to $90 \%$ of gelatinous predator diets (Purcell 1985). It is assumed that the majority of eggs are actively predated in the Gulf of Alaska (Kim \& Gunderson 1989), yet some fraction of eggs likely die of natural mortality and are incorporated into microbial pathways or sink and become available to benthic consumers. How these resource pathways are partitioned should be a future avenue of research, as this is not well resolved and likely varies spatially and temporally.

In the Gulf of Alaska, walleye pollock eggs are spawned at depth (Napp et al. 1996), and their vertical distribution differs from zooplankton that are primarily abundant in the upper 50 to $100 \mathrm{~m}$ (Napp et al. 1996). As a dietary resource, eggs may be particularly important for predators that forage in deeper waters (Bailey et al. 1993, Brodeur \& Merati 1993), either permanently or during vertical migrations. The deeper vertical distribution of eggs also suggests that benthic consumption may be important, and egg resources may represent an important component to benthic-pelagic coupling in Shelikof Strait. In other ecosystems, invertebrate predation of fish eggs has been shown for a range of marine and freshwater species (Polis et al. 1997, Schindler et al. 2003, Taylor \& Dunn 2017), while larger predators, including teleosts, sharks, and whales are known to forage efficiently during spawning aggregations (Varpe et al. 2005, Nemeth 2009). Our analyses on walleye pollock concur with these general findings that egg boons can provide an important, but alternative, resource pathway to bottom-up derived production (Fuiman et al. 2015), which is likely used by a range of decomposers and predators in marine food webs.

\subsection{Phenology of egg boons}

In marine ecosystems, the timing of resource availability is of primary importance for the survival, reproduction and growth of animals (Neuheimer et al. 2018). The spawning phenology of walleye pollock varies inter-annually by up to $3 \mathrm{wk}$ (Rogers \& Dougherty 2019). Walleye pollock spawn just before the initiation of the spring bloom, resulting in optimal feeding conditions when the surviving larvae start feeding after approximately $3 \mathrm{wk}$ (Porter \& Theilacker 1999, Laurel et al. 2010). The timing of the peak abundance of the CV stages of $N$. cristatus and Neocalanus spp. served as a proxy for zooplankton phenology and occurred several weeks after the initiation of the spring bloom. Despite the uncertainty in the exact timing of peak abundance of the CV stages, our estimates are in good agreement with other studies showing that peak biomass in spring is dominated by these 2 congeners (Coyle $\&$ Pinchuk 2003, Sousa et al. 2016). Furthermore, an examination of our empirical data on CV abundance for these 2 taxa shows a window for the timing of peak CV abundance (Fig. S7) that is similar to the model estimates. Average peak production of fish eggs commonly occurred 10-20 d before the increase in zooplankton production. Years with early egg production, in particular, preceded zooplankton development, and were also characterized by higher total egg production. Consequently, in most years, the timing of peak egg production precedes the increase in zooplankton production, suggesting that walleye pollock eggs appear at a crucial time when planktivorous consumers may be otherwise resource limited.

\subsection{Uncertainties in production estimates}

The purpose of our study was to evaluate the potential importance of the resource contribution of eggs to the marine food web. Upscaling empirically measured processes to the ecosystem level carries noticeable uncertainty. The sensitivity analysis showed that female fecundity and egg weights were the most influential parameters; however, no single parameter altered estimates of egg production by more than $25 \%$ (Fig. S4). Lower egg mortalities would have influenced our estimates, but it is unlikely that we consistently underestimated egg mortalities since we used a relatively modest value of $0.2 \mathrm{~d}^{-1}$, which is well within the range of previous estimates for walleye pollock (Kim \& Gunderson 1989). In addition, we did not model the contribution of endogenously feeding larvae, although this would be a likely additional resource contribution to the food web, since mortality rates of fish larvae at hatch are also commonly high 
(Peck et al. 2012). Our estimates of egg numbers based on acoustic survey data (Dorn et al. 2017) were similar to previous empirical estimates of total egg numbers for walleye pollock (Fig. S3, Picquelle \& Megrey 1993) and comparable to a range of other teleosts (Fuiman et al. 2015).

Zooplankton production rates are difficult to estimate empirically (Poulet et al. 1995). Using the equations of Hirst \& Lampitt (1998), Coyle \& Pinchuk (2003) estimated that copepod production along the Alaska shelf in April was $31 \mathrm{mgC} \mathrm{m}^{-2} \mathrm{~d}^{-1}$ which compares well to our average estimates of $37.5 \mathrm{mgC} \mathrm{m}^{-2}$ $\mathrm{d}^{-1}$. Our May production estimates based on coastal data were higher, on average at $121.0 \mathrm{mgC} \mathrm{m}^{-2} \mathrm{~d}^{-1}$, compared to their estimate of $35 \mathrm{mgC} \mathrm{m}^{-2} \mathrm{~d}^{-1}$ (Coyle \& Pinchuk 2003), which included both coastal and deeper stations. It should be noted that our production estimates represent only the copepod fraction of the zooplankton production, excluding organisms such as euphausiids, amphipods, appendicularians, pteropods and other decapods. Overall, fish egg and zooplankton production estimates are unlikely to have been consistently biased, and thus should provide good approximations for evaluating the relative magnitudes of egg and zooplankton production in the Shelikof Strait ecosystem in spring.

Obtaining robust measures of egg production phenology and zooplankton CV development times involves uncertainty. Spawn timing was estimated from larval walleye pollock captured in late May to early June, and while the larval fish surveys generally covered the period of peak larval abundance (Matarese et al. 2003), the earliest and latest-spawned larvae may have been under-sampled, resulting in an underestimate of the spawning duration (Rogers \& Dougherty 2019). However, any bias is likely to be small, and inter-annual variation in the timing of spawning generally agrees with other data sources (Rogers \& Dougherty 2019 and references therein). The development times calculated for $N$. cristatus (165-180 d after their release date of 15 November) appear to match well with other studies. Tsuda et al. (2004) reported that $N$. cristatus went from the egg stage to $\mathrm{C} 1$ in about $40 \mathrm{~d}$ at $2^{\circ} \mathrm{C}$ and Kobari \& Ikeda (1999) reported that development from CI to CV took $120 \mathrm{~d}$. The temperatures observed by Kobari \& Ikeda (1999) ranged from $2-3^{\circ} \mathrm{C}$ throughout the water column until April, when surface temperatures began to rise and about 1 mo prior to the local peak in $\mathrm{CV}$ abundance. This gives a total development time from egg to CV of approximately $160 \mathrm{~d}$, which with an egg release time of mid-November results in development to CV occurring around DOY 125-135, similar to our estimates and previous work (Miller et al. 1984). For Neocalanus spp., our range of 113-122 d matches well with $120 \mathrm{~d}$ reported by Miller \& Nielsen (1988) and 119-123 d reported by Liu \& Hopcroft (2006). Moreover, these estimates were well supported by the long-term empirical data, which showed peak abundance of both CV Neocalanus stages occurring in mid-May (DOY 125-150; Fig. S7), consistently later than our estimates of peak walleye pollock egg production.

\subsection{Importance of egg boons for ecosystem dynamics}

Fish spawning aggregations create important nutritional subsidies in marine systems (Polis et al. 1997, Varpe et al. 2005, Fuiman et al. 2015), as shown here for walleye pollock, and in freshwater systems (Schindler et al. 2003). Spawning events also increase nitrogen and phosphorus fluxes (Post \& Walters 2009) and can thus fuel primary production (Archer et al. 2015). We estimated egg production in terms of carbon production; however, eggs are rich in long-chained polyunsaturated fatty acids (PUFAs) (Laurel et al. 2010). Fuiman et al. (2015) highlighted that fish eggs are 10, 5 and 70 times richer in the essential long-chained PUFAs docosahexaenoic acid (22:6 3), eicosapentaenoic acid (20:5 3) and arachidonic acid (20:4 6), respectively, compared to zooplankton species, mostly from temperate regions. However, many boreal zooplankton species contain and store substantial amounts of lipids (Lee et al. 2006), thus the differences between the amount of essential long-chained PUFAs in eggs and zooplankton are likely smaller in the Gulf of Alaska and other higher-latitude ecosystems. Nonetheless, walleye pollock eggs likely provide an important lipid subsidy, including essential long-chained PUFAs, which is an important but at times limited resource in the Gulf of Alaska food web (Litzow et al. 2006).

Different fish populations have unique life histories and spawning modes, and their energetic inputs vary substantially in time and space. For example, in the Gulf of Alaska a proportion of walleye pollock spawns considerably earlier near the Shumagin Islands compared to the rest of the population (Dougherty et al. 2007). It should be noted that the spawning biomass of walleye pollock is high relative to other fish species, and thus variations in walleye pollock spawning biomass may have large impacts on seasonal egg energy input to the system, a phenomenon that is likely common across ecosystems that are dominated 
by selected species (e.g. sardines and anchovies in upwelling regions). Nonetheless, in the Gulf of Alaska, other abundant species such as Pacific halibut Hippoglossus stenolepis, arrowtooth flounder Atheresthes stomias and Pacific cod Gadus macrocephalus have very high fecundities (3-4 million eggs per female) and thus large energetic capacities for supporting ecosystem production. Furthermore, Pacific halibut eggs contain significant amounts of energy due to their large size (diameter of 2.9-3.8 $\mathrm{mm}$ ), and along with arrowtooth flounder, spawn from December to March (Matarese et al. 2003), well before the spring bloom, at a time period when other nutritional resources are scarce. Combined, the egg resource pulses from species which differ in their respective time of spawning could provide an extended wave of pulsed egg resources to the Gulf of Alaska food web, similar to what has been observed for salmon and Pacific herring in other ecosystems (Armstrong et al. 2016). Likewise, in other ecosystems, aggregate spawners such as Atlantic herring (Van Damme et al. 2009), Pacific herring (Fox et al. 2014, 2018) and Atlantic cod (Kjesbu et al. 1991) all deposit large energy subsidies to their respective environments. If transient energy pulses from different species provide considerable resource contributions to the ecosystem, it also implies that maintaining a diverse fish community and protecting spawning locations (Erisman et al. 2017) are essential for preserving high production levels in marine food webs. Furthermore, exploitation of individuals from the adult population not only impacts recruitment potential of the particular target species, it also diminishes or in severe cases removes (Hutchings \& Myers 1994) eggs as resource subsidies for other consumers. A reduction of the egg resource flux even at sustainable harvesting rates due to removal of spawning capacity will alter the flow of nutrients in the food web and should be an additional consideration for ecosystem-based fisheries management.

Acknowledgements. We are grateful to Martin Dorn, Adam Spear, Matt Wilson, Richard Brodeur, Jeff Napp, Esther Goldstein, Nissa Ferm and 3 anonymous reviewers for valuable inputs that substantially improved the manuscript, and to the National Research Council fellowship awarded to J.M.N. We also thank the numerous people who have worked on the long-term surveys and previous empirical studies that made the analyses in this paper possible. We thank the Plankton Sorting and Identification Center (Morski Instytyt Rybacki) in Sczcecin, Poland, and the zooplankton and ichthyoplankton teams at the Alaska Fisheries Science Center for their taxonomic expertise. The findings and conclusions in the paper are those of the authors and do not necessarily represent the views of the National Marine Fisheries Serv- ice. Mention of trade names does not imply endorsement by NOAA or any of its sub-agencies. This is contribution number EcoFOCI-0914 of Ecosystems and Fisheries-Oceanography Coordinated Investigations.

\section{LITERATURE CITED}

Adams CF, Pinchuk AI, Coyle KO (2007) Seasonal changes in the diet composition and prey selection of walleye pollock (Theragra chalcogramma) in the northern Gulf of Alaska. Fish Res 84:378-389

Archer SK, Allgeier JE, Semmens BX, Heppell SA and others (2015) Hot moments in spawning aggregations: implications for ecosystem-scale nutrient cycling. Coral Reefs 34:19-23

Armstrong JB, Takimoto GT, Schindler DE, Hayes MM, Kauffman MJ (2016) Resource waves: phenological diversity enhances foraging opportunities for mobile consumers. Ecology 97:1099-1112

Bailey KM, Brodeur RD, Merati N, Yoklavich MM (1993) Predation on walleye pollock (Theragra chalcogramma) eggs and yolk-sac larvae by pelagic crustacean invertebrates in the western Gulf of Alaska. Fish Oceanogr 2: 30-39

Bamstedt U (1986) Chemical composition and energy content. In: Corner EDS, O'Hara SCM (eds) The biological chemistry of marine copepods. Clarendon Press, New York, NY, p 1-58

* Barneche DR, Robertson DR, White CR, Marshall DJ (2018) Fish reproductive-energy output increases disproportionately with body size. Science 360:642-645

*Behrenfeld MJ, Falkowski PG (1997) Photosynthetic rates derived from satellite based chlorophyll concentration. Limnol Oceanogr 42:1-20

Blood DM (1994) Embryonic development of walleye pollock, Theragra chalcogramma, from Shelikof Strait, Gulf of Alaska. Fish Bull 92:207-222

*Brett M, Muller Navarra D (1997) The role of highly unsaturated fatty acids in aquatic foodweb processes. Freshw Biol 38:483-499

Brodeur RD, Merati N (1993) Predation on walleye pollock (Theragra chalcogramma) eggs in the western Gulf of Alaska: the roles of vertebrate and invertebrate predators. Mar Biol 117:483-493

* Brodeur RD, Bailey KM, Kim S (1991) Cannibalism on eggs by walleye pollock Theragra chalcogramma in Shelikof Strait, Gulf of Alaska. Mar Ecol Prog Ser 71:207-218

Brodeur RD, Picquelle SJ, Blood DM, Merati N (1996) Walleye pollock egg distribution and mortality in the western Gulf of Alaska. Fish Oceanogr 5:92-111

Bunn N, Fox C, Webb T (2000) A literature review of studies on fish egg mortality: implications for the estimation of spawning stock biomass by the annual egg production method. Centre for Environment, Fisheries and Aquaculture Science, Lowestoft

Burrow JF, Horwood JW, Pitchford JW (2011) The importance of variable timing and abundance of prey for fish larval recruitment. J Plankton Res 33:1153-1162

* Chmura HE, Kharouba HM, Ashander J, Ehlman SM, Rivest EB, Yang LH (2019) The mechanisms of phenology: the patterns and processes of phenological shifts. Ecol Monogr 89:e01337

* Ciannelli L, Bailey KM, Chan KS, Belgrano A, Stenseth NC (2005) Climate change causing phase transitions of wall- 
eye pollock (Theragra chalcogramma) recruitment dynamics. Proc R Soc B 272:1735-1743

Coyle KO, Pinchuk AI (2003) Annual cycle of zooplankton abundance, biomass and production on the northern Gulf of Alaska shelf, October 1997 through October 2000. Fish Oceanogr 12:327-338

Coyle KO, Pinchuk AI (2005) Seasonal cross-shelf distribution of major zooplankton taxa on the northern Gulf of Alaska shelf relative to water mass properties, species depth preferences and vertical migration behavior. Deep Sea Res II 52:217-245

Cushing DH (1990) Plankton production and year-class strength in fish populations: an update of the match/mismatch hypothesis. Adv Mar Biol 26:249-293

Dorn M, Aydin K, Fissel B, Jones D, McCarthy A, Palsson W, Spalinger K (2017) Chapter 1: Assessment of the walleye pollock stock in the Gulf of Alaska. In: Stock assessment and fishery evaluation report for the groundfish resources of the Gulf of Alaska for 2017. North Pacific Fishery Management Council, Anchorage, AK, p 47-182

Dougherty A, Bailey K, Mier K (2007) Interannual differences in growth and hatch date distributions of age 0 year walleye pollock Theragra chalcogramma (Pallas) sampled from the Shumagin Islands region of the Gulf of Alaska, 1985-2001. J Fish Biol 71:763-780

Ellis T, Nash R (1997) Predation by sprat and herring on pelagic fish eggs in a plaice spawning area in the Irish Sea. J Fish Biol 50:1195-1202

Erisman B, Heyman W, Kobara S, Ezer T, Pittman S, AburtoOropeza O, Nemeth RS (2017) Fish spawning aggregations: where well-placed management actions can yield big benefits for fisheries and conservation. Fish Fish 18: 128-144

Fox CH, El-Sabaawi R, Paquet PC, Reimchen TE (2014) Pacific herring Clupea pallasii and wrack macrophytes subsidize semi-terrestrial detritivores. Mar Ecol Prog Ser 495:49-64

Fox CH, Paquet PC, Reimchen TE (2018) Pacific herring spawn events influence nearshore subtidal and intertidal species. Mar Ecol Prog Ser 595:157-169

Fuiman LA (2018) Egg boon fatty acids reveal effects of a climatic event on a marine food web. Ecol Monogr 88: 585-599

Fuiman LA, Connelly TL, Lowerre-Barbieri SK, McClelland JW (2015) Egg boons: central components of marine fatty acid food webs. Ecology 96:362-372

* Harris R, Nishiyama T, Paul A (1986) Carbon, nitrogen and caloric content of eggs, larvae, and juveniles of the walleye pollock, Theragra chalcogramma. J Fish Biol 29:87-98

Hinckley S (1990) Variation in egg size of walleye pollock Theragra chalcogramma with a preliminary examination of the effect of egg size on larval size. Fish Bull 88: $471-483$

Hirst A, Lampitt R (1998) Towards a global model of in situ weight-specific growth in marine planktonic copepods. Mar Biol 132:247-257

Hjort J (1914) Fluctuations in the great fisheries of northern Europe viewed in the light of biological research. J Cons Int Explor Mer 20:1-228

*Holt RD (2008) Theoretical perspectives on resource pulses. Ecology 89:671-681

Hunter J (1980) Egg cannibalism in the northern anchovy, Engraulis mordax. Fish Bull 78:811-816

Hutchings JA, Myers RA (1994) What can be learned from the collapse of a renewable resource? Atlantic cod, Gadus morhua, of Newfoundland and Labrador. Can J Fish Aquat Sci 51:2126-2146

Jenkins DG (2015) Estimating ecological production from biomass. Ecosphere 6:49

Jentsch A, White P (2019) A theory of pulse dynamics and disturbance in ecology. Ecology 100:e02734

Kendall A (1994) The vertical distribution of eggs and larvae of walleye pollock, Theragra chalcogramma, in Shelikof Strait, Gulf of Alaska. Fish Bull 92:540-554

KKendall JAW, Schumacher JD, Kim S (1996) Walleye pollock recruitment in Shelikof Strait: applied fisheries oceanography. Fish Oceanogr 5:4-18

Kharouba HM, Ehrlén J, Gelman A, Bolmgren K, Allen JM, Travers SE, Wolkovich EM (2018) Global shifts in the phenological synchrony of species interactions over recent decades. Proc Natl Acad Sci USA 115:5211-5216

*Kim S, Gunderson DR (1989) Cohort dynamics of walleye pollock in Shelikof Strait, Gulf of Alaska, during the egg and larval periods. Trans Am Fish Soc 118:264-273

Kimmel DG, Eisner LB, Wilson MT, Duffy-Anderson JT (2018) Copepod dynamics across warm and cold periods in the eastern Bering Sea: implications for walleye pollock (Gadus chalcogrammus) and the Oscillating Control Hypothesis. Fish Oceanogr 27:143-158

Kiørboe T, Hirst AG (2008) Optimal development time in pelagic copepods. Mar Ecol Prog Ser 367:15-22

Kjesbu O, Klungsøyr J, Kryvi H, Witthames P, Walker MG (1991) Fecundity, atresia, and egg size of captive Atlantic cod (Gadus morhua) in relation to proximate body composition. Can J Fish Aquat Sci 48:2333-2343

Kobari T, Ikeda T (1999) Vertical distribution, population structure and life cycle of Neocalanus cristatus (Crustacea: Copepoda) in the Oyashio region, with notes on its regional variations. Mar Biol 134:683-696

Kuribayashi T, Abe T, Montani S (2017) Historical $\delta^{15} \mathrm{~N}$ records of Saccharina specimens from oligotrophic waters of Japan Sea (Hokkaido). PLOS ONE 12:e0180760

KLaurel BJ, Copeman LA, Hurst TP, Parrish CC (2010) The ecological significance of lipid/fatty acid synthesis in developing eggs and newly hatched larvae of Pacific cod (Gadus macrocephalus). Mar Biol 157:1713-1724

Laurel BJ, Copeman LA, Spencer M, Iseri P (2018) Comparative effects of temperature on rates of development and survival of eggs and yolk-sac larvae of Arctic cod (Boreogadus saida) and walleye pollock (Gadus chalcogrammus). ICES J Mar Sci 75:2403-2412

Lee RF, Hagen W, Kattner G (2006) Lipid storage in marine zooplankton. Mar Ecol Prog Ser 307:273-306

* Lewandowska AM, Striebel M, Feudel U, Hillebrand $H$, Sommer U (2015) The importance of phytoplankton trait variability in spring bloom formation. ICES J Mar Sci 72: 1908-1915

* Litzow MA, Bailey KM, Prahl FG, Heintz R (2006) Climate regime shifts and reorganization of fish communities: the essential fatty acid limitation hypothesis. Mar Ecol Prog Ser 315:1-11

Liu H, Hopcroft RR (2006) Growth and development of Neocalanus flemingeri/plumchrus in the northern Gulf of Alaska: validation of the artificial-cohort method in cold waters. J Plankton Res 28:87-101

Llopiz J, Cowen R, Hauff M, Ji R and others (2014) Early life history and fisheries oceanography: new questions in a changing world. Oceanography 27:26-41

Lok EK, Esler D, Takekawa JY, De La Cruz SW and others (2012) Spatiotemporal associations between Pacific her- 
ring spawn and surf scoter spring migration: evaluating a 'silver wave' hypothesis. Mar Ecol Prog Ser 457:139-150 Matarese AC, Blood DM, Picquelle SJ, Benson JL (2003) Atlas of abundance and distribution patterns of ichthyoplankton from the Northeast Pacific Ocean and Bering Sea ecosystems: based on research conducted by the Alaska Fisheries Science Center (1972-1996). NOAA Prof Pap NMFS 1. U.S. Department of Commerce, National Oceanic and Atmospheric Administration, National Marine Fisheries Service, Seattle, WA

Miller CB, Nielsen RD (1988) Development and growth of large, calanid copepods in the ocean subarctic Pacific, May 1984. Prog Oceanogr 20:275-292

Miller CB, Frost BW, Batchelder HP, Clemons MJ, Conway RE (1984) Life histories of large, grazing copepods in a subarctic ocean gyre: Neocalanus plumchrus, Neocalanus cristatus, and Eucalanus bungii in the Northeast Pacific. Prog Oceanogr 13:201-243

Miller B, Gunderson D, Glass D, Powell D, Megrey B (1986) Fecundity of walleye pollock (Theragra chalcogramma) from the Shelikof Strait, Gulf of Alaska. Fisheries Research Institute, University of Washington, Seattle, WA

Napp JM, Incze LS, Ortner PB, Siefert DL, Britt L (1996) The plankton of Shelikof Strait, Alaska: standing stock, production, mesoscale variability and their relevance to larval fish survival. Fish Oceanogr 5:19-38

Nemeth RS (2009) Dynamics of reef fish and decapod crustacean spawning aggregations: underlying mechanisms, habitat linkages, and trophic interactions. In: Nagelkerken I (ed) Ecological connectivity among tropical coastal ecosystems. Springer, Dordrecht, p 73-134

Neuheimer AB, MacKenzie BR, Payne MR (2018) Temperature-dependent adaptation allows fish to meet their food across their species' range. Sci Adv 4:eaar4349

Peck MA, Huebert KB, Llopiz JK (2012) Intrinsic and extrinsic factors driving match-mismatch dynamics during the early life history of marine fishes. Adv Ecol Res 47:177-302

Picquelle S, Megrey B (1993) A preliminary spawning biomass estimate of walleye pollock, Theragra chalcogramma, in the Shelikof Strait, Alaska, based on the annual egg production method. Bull Mar Sci 53:728-749

Platt T, Fuentes-Yaco C, Frank KT (2003) Spring algal bloom and larval fish survival. Nature 423:398-399

Polis GA, Anderson WB, Holt RD (1997) Toward an integration of landscape and food web ecology: the dynamics of spatially subsidized food webs. Annu Rev Ecol Syst 28: 289-316

Porter SM, Theilacker GH (1999) The development of the digestive tract and eye in larval walleye pollock, Theragra chalcogramma. Fish Bull 97:722-729

Post DM, Walters AW (2009) Nutrient excretion rates of anadromous alewives during their spawning migration. Trans Am Fish Soc 138:264-268

Poulet S, Ianora A, Laabir M, Breteler WK (1995) Towards the measurement of secondary production and recruitment in copepods. ICES J Mar Sci 52:359-368

Purcell JE (1985) Predation on fish eggs and larvae by pelagic cnidarians and ctenophores. Bull Mar Sci 37: 739-755

Editorial responsibility: Stephen Wing, Dunedin, New Zealand
R Core Team (2018) R: a language and environment for statistical computing. R Foundation for Statistical Computing, Vienna

Richardson JS, Wipfli MS (2016) Getting quantitative about consequences of cross-ecosystem resource subsidies on recipient consumers. Can J Fish Aquat Sci 73:1609-1615

* Rogers LA, Dougherty AB (2019) Effects of climate and demography on reproductive phenology of a harvested marine fish population. Glob Change Biol 25:708-720

Sarkar N, Royer TC, Grosch CE (2005) Hydrographic and mixed layer depth variability on the shelf in the northern Gulf of Alaska, 1974-1998. Cont Shelf Res 25:2147-2162

Schindler DE, Scheuerell MD, Moore JW, Gende SM, Francis TB, Palen WJ (2003) Pacific salmon and the ecology of coastal ecosystems. Front Ecol Environ 1:31-37

米留ejkal M, Ricard D, Vejřík L, Mrkvička T and others (2017) Seasonal and daily protandry in a cyprinid fish. Sci Rep $7: 4737$

Sousa L, Coyle KO, Barry RP, Weingartner TJ, Hopcroft RR (2016) Climate-related variability in abundance of mesozooplankton in the northern Gulf of Alaska 1998-2009. Deep Sea Res II 132:122-135

Springer AM (1992) A review: walleye pollock in the North Pacific-How much difference do they really make? Fish Oceanogr 1:80-96

Stienessen S, McCarthy AL, Jones D, Honkalehto T (2017) Results of the acoustic-trawl surveys of walleye pollock (Gadus chalcogrammus) in the Gulf of Alaska, FebruaryMarch 2016 (DY2016-02 and DY2016-04). AFSC Processed Rep 2017-02. NOAA, NMFS, AFSC, Seattle, WA

Taylor NG, Dunn AM (2017) Size matters: predation of fish eggs and larvae by native and invasive amphipods. Biol Invasions 19:89-107

* Tsuda A, Saito H, Kasai H (2004) Life histories of Eucalanus bungii and Neocalanus cristatus (Copepoda: Calanoida) in the western subarctic Pacific Ocean. Fish Oceanogr 13:10-20

*Urban D (2012) Food habits of Pacific cod and walleye pollock in the northern Gulf of Alaska. Mar Ecol Prog Ser 469:215-222

*van Damme CJG, Dickey-Collas M, Rijnsdorp AD, Kjesbu OS (2009) Fecundity, atresia, and spawning strategies of Atlantic herring (Clupea harengus). Can J Fish Aquat Sci 66:2130-2141

*van Deurs M, Persson A, Lindegren M, Jacobsen C, Neuenfeldt S, Jørgensen C, Nilsson PA (2016) Marine ecosystem connectivity mediated by migrant-resident interactions and the concomitant cross system flux of lipids. Ecol Evol 6:4076-4087

Varpe $\varnothing$, Fiksen $\varnothing$, Slotte A (2005) Meta-ecosystems and biological energy transport from ocean to coast: the ecological importance of herring migration. Oecologia 146:443

* Waite JN, Mueter FJ (2013) Spatial and temporal variability of chlorophyll-a concentrations in the coastal Gulf of Alaska, 1998-2011, using cloud-free reconstructions of SeaWiFS and MODIS-Aqua data. Prog Oceanogr 116:179-192

*Yang LH, Naeem S (2008) The ecology of resource pulses. Ecology 89:619-620

Y Yang LH, Bastow JL, Spence KO, Wright AN (2008) What can we learn from resource pulses? Ecology 89:621-634

Submitted: June 25, 2019; Accepted: November 6, 2019

Proofs received from author(s): December 2, 2019 